\title{
EU Court overrules France's Bt maize ban
}

On 21 March, the European Court of Justice (Luxembourg) said that France's highest court, the Conseil d'État, was wrong in its 1998 decision to block the commercialization of Novartis Seeds' (Basel, Switzerland) Bt maize, which contains the gene conferring antibiotic resistance to ampicillin. The court ruled that France must respect the European Commission's (EC) 1997 decision to authorize EU-wide commercialization of the maize because it was French authorities that originally recommended approval of the crop. Ironically, both Novartis and environmental group Greenpeace welcome the decisionNovartis because it endorses its product's safety, and Greenpeace because it could prompt France to legally challenge the EC's original decision.

Back in 1996, the French government supported Novartis' application of three $B t$ 176 maize varieties for commercialization at the EU level-a decision that was approved by the EC in 1997. Under normal procedure, France's national plant registration office was subsequently required to license the $B t$ maize for its own market, which it did. However, claims by Greenpeace that the French government had failed to properly assess the impact of the ampicillin-resistance gene on public health when it had originally supported Novartis's application prompted the Conseil d'État to suspend commercialization of the maize in France in September 1998. The decision was based on the grounds that France had not followed the precautionary principle laid out in the EU directive $90 / 220$ for deliberate release of GMOs into the environment and in French constitution, and the Conseil d'État called upon the European Court of Justice to rule on the matter.

According to the European Court, "A member state that has forwarded an application with a favorable opinion must authorize the GMO to be placed on the market after the Commission has adopted a favorable decision." But the court also recognizes the right for an individual EU country to apply for a national ban on a crop that it or the EC previously approved, if new information reveals a health or environmental risk. For instance, earlier this year Germany revoked a safety license issued to Novartis for Bt maize 176 (Nature Biotechnology 18, 374, 2000), and Luxembourg and Austria both rejected the maize in 1997-all on the basis of antibiotic resistance safety concerns.

Sabine Louët is a freelancer working in London.
In France's case, however, the European court, after consulting three groups of scientific experts, was unable to substantiate France's claims that French authorities had originally failed to properly assess the impact of antibiotic resistance genes on public health when supporting Novartis' application. Therefore, it has ruled that the EC's EU-wide authorization is upheld and France is unable to revoke its previous approval of the maize.

Unsurprisingly, Novartis welcomes the decision, claiming a sanction of its product. "We gain credibility from the word of the highest court in Europe," says Willy De Greef, head of regulatory affairs at Novartis Seeds. "We are collecting endorsement on our quality of safety [testing]," he adds.

Ironically, the court's judgement has also been received favorably by Greenpeace, which claims that the ruling is one step closer toward a European ban of the Bt maize. "This judgement is a major advance on the GMO question in Europe," says Greenpeace France's director Bruno Rebelle, "The European Court of Justice is opening the door for the French Conseil d'État to confirm the doubts that led to the ban of transgenic maize."

Indeed, according to Herve Reverbori, head of food regulation and biotechnology at the French Agriculture and Fishery Ministry (Ministère de l'Agriculture et de la Pêche), if the Conseil d'État rejects the European Court's ruling and decides that the EC's original EU-wide approval of the crop is not valid, it can challenge that decision by the EC via the European Court of
Justice-a case that will focus on interpretation of the law by looking at its scientific validity.

Should the Conseil d'Etat decide to challenge the original EC ruling, the case will be reviewed under the long-awaited revised version of the 90/220 directive, which was finalized following a vote in the European parliament on April 12. While the new 90/220 does not explicitly ban the use of antibiotic resistance marker genes in crops, the European Parliament has resolved to phase out their use by 2005 .

One of the aims of the revised directive is to centralize the GMO release procedure at community level through such bodies as the European Environment Agency or the proposed European Food Authority-a move that should eliminate this sort of individual country opposition to EU rulings.

Meanwhile, increasing opposition to GMOs suggests restricted use of $B t$ maize in any event. On April 5, for instance, the French parliamentary commission on food safety published a report recommending the banning of GMOs from the market on the grounds of a lack of clear markers to establish their harmlessness. And, according to the French General Association of Maize Producers (GAMP), even if $B t$ maize does find its way onto the market in France, consumer pressure will mean that French farmers, who produce 3.2 million hectares of maize per year-half of all maize produced by the EU-will not plant it. Says GAMP spokesman Christophe Labarde, "the only reality is the market."

Sabine Louët

\section{Biotech companies adapt to big pharma mergers}

As another round of lifescience company mergers proceeds, many biotech executives, analysts, and investors are anxiously waiting to see whether already-existing research collaborations will remain intact when new corporate managers take over. However, recognizing the potential threat to business, some companies have learnt to protect themselves by carefully constructed licensing contracts, while many are taking advantage of booming financial markets to raise what is, in effect, insurance money.

The merger between Monsanto (St Louis, MO) and Pharmacia \& Upjohn (P\&U; Peapack, NJ) was finalized in early April, while three other large pharmaceutical firms, or their agricultural divisions, undergo regulatory and stockholder
approval-Glaxo Wellcome (London)/SmithKline Beecham (London), WarnerLambert (Morris Plains, NJ)/Pfizer (New York), and Novartis (Basel, Switzerland)/AstraZeneca (London). Companies with alliances worry that there will be reshuffling and the future may not be dependable, says Steven Burrill, president of research investment firm Burrill \& Co. (San Francisco, CA) "The reorganization and new structures are going to cause some of the existing relationships to be more questionable."

Genomics-based biotech companies are the most likely to have overlapping research programs with merged entities, according to analysts. Incyte Genomics (Palo Alto, CA), for instance, has various agreements with five of the six merging pharmaceutical compa- 